\title{
EQUAL PAY AND EU PUBLIC PROCUREMENT LAW - CASE STUDY OF MANDATORY ICELANDIC ÍST85 STANDARD
}

\author{
MARTA ANDHOV* \& BERGPÓR BERGSSON ${ }^{\dagger}$
}

\begin{abstract}
From 2018, it became mandatory to obtain the Icelandic Equal Pay Standard (IST85) for all companies with 25+ employees annually operating on the Icelandic market. It has been unclear to what extent - if any - the IST 85 can be applied in public procurements. This article analyses whether the IST85 is compliant with the relevant European Union internal market law, particularly public procurement law. The growing intensity of nudges to include and verify social elements in public procurements can be observed throughout the EU. The analysis of the Islandic case study bears relevance as it can be applied to the EU Member States and other EEA/EFTA States, contemplating similar approaches in their procurements. Section 1 introduces ÍST85. Section 2 analyses the relationship between EEA and EU law, showcasing that this article's analytical outcomes provide lessons applicable beyond Iceland. Section 3 examines how equal pay is regulated under EU law. Section 4 conducts an internal market analysis of IST85 compliance by examining the Treaties provisions on free movement. Section 5 introduces the EU public procurement law and examines IST85 compliance with Directive 2014/24/EU. Section 6 tests the application of IST85 to the Posted Workers Directive. Section 7 concludes the article.
\end{abstract}

\section{INTRODUCTION}

The Icelandic Equal Pay Standard, also known as IST85, ${ }^{1}$ was introduced in 2012 to close the gender pay gap in Iceland. It aims to ensure that women and men who work for the same employer are paid equal wages and enjoy equal terms of employment for the same jobs or jobs of equal value. The ÍST85 was voluntary until spring 2017, when the Icelandic government passed a law stipulating that from 1st January 2018, the ÍST85 is mandatory for all companies with $25+$ employees operating on the Icelandic market. ${ }^{2}$ The act has since been repealed and replaced, with the new version coming into force on $6^{\text {th }}$ January $2021 .^{3}$

The revised EU public procurement regime promotes sustainability in public procurement more broadly than ever before. ${ }^{4}$ Sustainable public procurement (SPP) is a

\footnotetext{
* Marta Andhov, associate professor at the Centre for Private Governance (CEPRI) Faculty of Law, University of Copenhagen, Denmark, e-mail: marta.andrecka@jur.ku.dk.

† Bergpór Bergsson LL.M. associate at DLA Piper. Our thanks to professors: Roberto Caranta, Catherine Bernard, Albert Sanchez-Graells, Martin Trybus and Xavier Groussot, as well as Dagmar Sigurðardóttir for commenting on an earlier drafts of this article.

1 The official name of the standard is ÍST 85:2012 - Equal wage management system - Requirements and guidance.

2 Act no. 10/2008 on Equal Status and Equal Rights of Women and Men, as amended by Amendment Act 56/2017 on Equal Pay Certification (Equal Rights Act).

3 Act no. 150/2020 on the Equal Status and Gender Equality (Gender Equality Act) and Act no. 151/2020 on the Administration of Gender Equality (Administration of Equality Act).

${ }^{4}$ Directive 2014/24/EU of the European Parliament and of the Council of 26 February 2014 on public procurement and repealing Directive 2004/18/EC (Directive 2014/24/EU) [2014] OJ L94/65; Directive 2014/25/EU of the European Parliament and of the Council of 26 February 2014 on procurement by
} 
'procurement that has the most positive environmental, social and economic impacts possible across the entire life cycle and that strives to minimise adverse impacts'. ${ }^{5}$ As a policy tool for including considerations other than solely economic ones when acquiring goods, works or services, SPP may address social issues such as equal pay for men and women. This can be done while aiming to achieve the appropriate balance between the economic, social and environmental factors, which are the three pillars of sustainable development. ${ }^{6}$ Recital 2 of Directive 2014/24/EU refers to the key role of public procurement in achieving the Europe 2020 strategy for smart, sustainable, and inclusive growth. This role is also evident in the Directive's ambition to enable 'procurers to make better use of public procurement in support of common societal goals'?

Viewed through the lens of universal values and progress, introducing a mandatory law on equal pay certification in Iceland should certainly be applauded. Yet, the initiative also poses uncertainties and questions regarding Icelandic public procurements. The Icelandic contracting authorities have been unsure whether the ÍST85 can be applied in public procurements and particularly to what extent it can be required from the foreign bidders to obtain the standard to bid for governmental contracts. More specifically, whether the ÍST85 is compliant with the European Union (EU) law and particularly with public procurement law. As a member of the European internal market through the agreement on the European Economic Area (EEA), Iceland must ensure that no trade restrictions are impeding free movement provisions (goods, services, capital and persons). By extension, Iceland is bound to comply with EU public procurement law. This means that to apply ÍST85 in public tenders, it must comply with the EU public procurement directives for the covered contracts and the general EU Treaties provisions for all procurements, including those outside the directives.

As Iceland is a pioneer in its approach to ensure equal pay, ÍST85 is used here as a case study. The outcomes of this analysis provide broader applicability than just Iceland. Keeping in mind the growing intensity of nudges to include social elements in public procurements, this analysis can be applied to the EU Member States, contemplating similar approaches in their procurements.

This article aims to test whether Iceland's mandatory ÍST85 is compliant with relevant EU internal market law. It is structured sectionally. Section 2 introduces ÍST85. Section 3 analyses the relationship between EEA and EU law, showcasing that this article's analytical outcomes provide lessons applicable beyond Iceland. Section 4 examines how equal pay is regulated under EU law. Section 5 conducts an internal market analysis of ÍST85 compliance by examining the Treaties provisions on free movement. Section 6 introduces the EU public procurement law and examines ÍST85 compliance with Directive 2014/24/EU. Section 7

entities operating in the water, energy, transport and postal services sectors and repealing Directive 2004/17/EC [2014] OJ L94/243, and Directive 2014/23/EU of the European Parliament and of the Council of 26 February 2014 on the award of concession contracts [2014] OJ L94/1. For an overview of the reform, see G Skovgaard Ølykke and A Sánchez Graells (eds), Reformation or Deformation of the EU Public Procurement Rules (Edward Elgar 2016).

${ }^{5}$ International Organisation for Standarisation (ISO) ISO 20400:2017.

${ }^{6}$ See M Andhov, 'Contracting authorities and strategic goals of public procurement - a relationship defined by discretion?' in S Bogojevic, X Groussot, J Hettne (eds) Discretion in EU Procurement Law (Hart Publishing 2019). EU Commission, 'Strategic Public Procurement: Facilitating Green, Inclusive and Innovative Growth' (2017) 12 European Procurement and Public-Private Partnership Law Review 220.

7 Recital 2 Directive 2014/24/EU. 
tests the application of ÍST85 to the Posted Workers Directive. Section 8 concludes the article.

\section{THE ICELANDIC EQUAL PAY STANDARD (ÍST85)}

ÍST85 was introduced as a result of a collaboration between the Minister of Welfare, the Icelandic Confederation of Labour, and the Confederation of Icelandic Enterprises in 2012. ÍST85 is a mechanism assisting employers with developing and implementing an equality policy and implementing a system for monitoring employees' wages. ${ }^{8}$ The aim is to ensure that all workers are receiving equal pay. ${ }^{9}$ The cornerstone of ÍST85 is implementing an equal pay management system that should include all of a company's employees. ${ }^{10}$ One aspect of implementing such a system involves defining and categorising all the positions within a company based on objective and appropriate criteria, thereby providing an effective and professional method for pay decisions. ${ }^{11}$

From 2018, ÍST85 became mandatory for all companies with 25+ employees annually operating on the Icelandic market. ${ }^{12}$ The primary reasoning for making ÍST85 mandatory was to take a big step towards closing the gender gap in the Icelandic labour market. Although Iceland has occupied the top spot in the World Economic Forum's Global Gender Gap Report for ten years, the memorandum to the Equal Rights Act's legislative amendments suggests there is still a $5.6 \%-13.7 \%$ gender pay gap. ${ }^{13}$ Such a situation is deemed unacceptable since Iceland is obliged to prevent discrimination - which includes pay inequality - by both Article 65 of the Icelandic Constitution and its international obligations. ${ }^{14}$ For example, Article 69 of the EEA agreement explicitly states that men and women should receive equal pay for equal work. ${ }^{15}$ Equally, this obligation follows from Article 4 of the Recast Directive ${ }^{16}$ and International Labour Organization's Convention no. $100 .^{17}$

Since ÍST85 became mandatory based on the Equal Rights Act, the act has since been repealed and replaced with the Gender Equality Act and the Administration of Equality Act.

\footnotetext{
${ }^{8}$ Art. 2(11) of the Gender Equality Act defines the term Equal Pay Certification.

${ }^{9}$ Art. 1 ÍST 85:2012.

10 Art. 4(1) ÍST 85:2012.

11 Art. 4(3)(1) ÍST 85:2012.

12 Art 19(4) Equal Status Act. The term 'company' is defined in Art 3 ÍST85:2012 as 'any entity, corporation, administrative authority or institution, or any other combination thereof, whatever its legal form, public or private, which has its own operations and senior management'.

13 World Economic Forum, 'The Global Gender Gap Report 2018' (2018), 18

<www3.weforum.org/docs/WEF_GGGR_2018.pdf> accessed 1 February 2021 and the Memorandum accompanying the legislative draft, $4-5<$ www.althingi.is/altext/pdf/146/s/0570.pdf > accessed 1 February 2021.

${ }^{14}$ Constitution of the Republic of Iceland Act no. 33 of 17 June 1944 with amendments.

15 Art. 69 of the EEA agreement is identical to Art. 6 in the Agreement on Social Policy concluded between the Member States of the European Community with the exception of the United Kingdom and Northern Ireland, which is a protocol to the Treaty on European Union (TEU) [2016] OJ C202/13. The article is a predecessor to the more specific Art. 157 of the Treaty on the Functioning of the European Union (TFEU) [2016] OJ C202/47.

${ }^{16}$ Directive 2006/54/EC on the implementation of the principle of equal opportunities and equal treatment of men and women in matters of employment and occupation (Recast Directive) [2006] OJ L 204/23.

17 ILO Convention C100 - Equal Remuneration Convention, 1951 (No. 100).
} 
The former addresses some of the initial shortcomings associated with the framework surrounding ÍST85.

The Gender Equality Act stipulates that a company covered by the law must attain a certification based on an audit attesting that the equal pay system it has implemented meets ÍST85 requirements. ${ }^{18}$ The certification is valid for three years. However, small companies with 25-49 employees rather than receiving a certification via an audit may receive a confirmation from the Directorate of Equality in Iceland. Such a confirmation is based on an inspection of documents that a company must provide to the Directorate. ${ }^{19}$ It should be noted that a parent company and its subsidiaries or a company group may receive a joint equal pay certification. ${ }^{20}$

Due to the burden created by ÍST85's obligations, the law from 2018 contained an interim provision addressing when companies must have acquired certification or confirmation concerning their ÍST85 implementation. The period depends on the company's size, with the largest companies implementing the system first. ${ }^{21}$ If companies fail to obtain ÍST85 certification, they are subject to fines upwards of 50,000 ISK $(\sim 330 €)$ per day. ${ }^{22}$ As of 16th April 2021, 299 companies and institutions have acquired an ÍST85 certification. ${ }^{23}$

\begin{tabular}{|c|l|c|}
\hline $\begin{array}{c}\text { No. of } \\
\text { employees } \\
\text { on an } \\
\text { annual } \\
\text { basis }\end{array}$ & \multicolumn{1}{|c|}{ Type of company } & \multicolumn{1}{|c|}{ Date } \\
\hline $25+$ & Government Ministries ${ }^{24}$ & \\
\hline $250+$ & Companies and institutions & 31 st December 2018 \\
\hline $25+$ & $\begin{array}{l}\text { Public institutions, funds or companies that are half- } \\
\text { owned or more by the state }\end{array}$ & 31 st December $2019^{25}$ \\
\hline $150-249$ & Companies and institutions & 31 st December 2019 \\
\hline $90-149$ & Companies and institutions 2020 \\
\hline $25-89$ & Companies and institutions & 31 st December 2021 \\
\hline & & 31 st December 2022 \\
\hline
\end{tabular}

\footnotetext{
18 Art. 7(1) Gender Equality Act.

${ }_{19}$ Art. 8(1) and Art. 8(2) Gender Equality Act. This exemption does not apply to public institutions, funds or companies that are half-owned or more by the state, cf. Art. 8(3) Gender Equality Act.

${ }^{20}$ Art. 7 Gender Equality Act and memorandum to the Act, 32-33.

${ }^{21}$ Interim provision I (1) Gender Equality Act.

22 Art. 10(1) Gender Equality Act, cf. Arts. 6(1) and 6(2) Administration of Equality Act.

${ }^{23}$ See the list of companies and institutions available at: Directorate of Equality, 'Listi yfir aðila sem hlotið hafa vottun' (updated 22 June 2021) <www.jafnretti.is/is/vinnumarkadur/jofn-laun-og-jafnirmoguleikar/listi-yfir-adila-sem-hlotid-hafa-vottun> accessed 5 August 2021.

${ }^{24}$ Government Ministries operating under the Icelandic Government Ministries Act no. 115/2011.

${ }^{25}$ A regulation was passed on 9 November 2018, changing the deadline for the implementation of ÍST85 by the biggest companies and public institutions from 31 December 2018 to 31 December 2019, as it was foreseen that a number of companies and ministries would not manage to fulfil their obligations and receive a certification in time. A subsequent regulation was passed on 6 December 2019 changing the deadline for companies with 150-249 employees, 90-149 employees and 25-89 employees, where the original deadline for implementation was moved one year into the future. These deadlines are also found in Interim provision I (1) Gender Equality Act.
} 
Table 1 Different times of implementation depending on the number of employees within a company. Source: Interim provision I of Gender Equality Act.

A newly established company with 25+ employees, or a company that previously fell outside the scope of the legislation but has grown to have $25+$ employees, has three years from the date when a change of circumstances triggered the applicability of ÍST85 to implement it. The reason for the three year grace period is to account for any fluctuations in the number of employees (a company may have a single busy year) and account for the time it may take to fulfil the requirements in ÍST85. ${ }^{26}$ Suppose a company fell within the scope of the legislation, but the employees' number has reduced to the extent that it no longer triggers the applicability of ÍST85. In that case, it is no longer mandatory to fulfil the requirements for obtaining the standard.

\subsection{LEGISLATIVE PROCESS}

During the legislative process of the Equal Rights Act establishing ÍST85 as mandatory, the Icelandic Parliament received comments from various stakeholders. Among these stakeholders was Icelandic Standards, a standards association that developed ÍST85. The association pointed out that standards should be optional, not mandatory. It cited the Regulation on European Standardisation and its explicit statement that standards are voluntary. ${ }^{27}$

At its inception, ÍST85 was written as a voluntary standard, and its set up was not designed in view of its application as a mandatory legal tool. Furthermore, ÍST85 has not been changed since 2012, and the Equal Rights Act did not take future amendments into account. As Icelandic Standards is the copyrighted owner of the ÍST85, the standard will be amended solely by Icelandic Standards, not by the parliament itself. The members of the association can exert influence on how ÍST85 standards are amended. One factor that warrants critique is that even though Icelandic Standards held copyright ownership of ÍST85, the Ministry of Welfare, which wrote the Equal Rights Act's legislative draft, never contacted the association or sought their assistance concerning the draft. ${ }^{28}$ This issue has been addressed in the new Gender Equality Act, where all references are to ÍST85:2012 and not to ÍST85. This is to prevent any misunderstanding about which version of the standard is mandatory to implement if Icelandic Standards decides to revise ÍST85. ${ }^{29}$

\footnotetext{
${ }^{26}$ Art. 7 Gender Equality Act and memorandum to the Act, 32-33.

${ }^{27}$ Recitals 1, 11 and Art. 2(1) Regulation (EU) No 1025/2012 of the European Parliament and of the Council of 25 October 2012 on European Standardisation, amending Council Directives 89/686/EEC and 93/15/EEC and Directives 94/9/EC, 94/25/EC, 95/16/EC, 97/23/EC, 98/34/EC, 2004/22/EC, 2007/23/EC, 2009/23/EC and 2009/105/EC of the European Parliament and of the Council and repealing Council Decision 87/95/EEC and Decision No 1673/2006/EC of the European Parliament and of the Council [2012] OJ L 316/12.

28 See 'Icelandic Standards comments', (Islenskir Staðlar, 5 May 2017)

$<$ www.althingi.is/altext/erindi/146/146-1156.pdf> accessed 30 March 2021.

29 'Memorandum to Gender Equality Act', (2020), 32 <www.althingi.is/altext/pdf/151/s/0014.pdf> accessed 30 March 2021. The memorandum specifically mentions that the motivation was to prevent any amendments to the standard that would circumvent the parliament. Interestingly, this was pre-emptively addressed by Icelandic Standards in their comments to the Equal Status Act, where it argued that amending
} 
Another criticism raised when introducing the mandatory ÍST85 focused on how inaccessible the standard was since companies had to purchase it despite its status as a legal requirement. ${ }^{30}$ While making standard mandatory accords with Article 3(1) of the Act on Standards and Icelandic Standards, the legislation does not address how accessible the standard in question should be. In response to this criticism, which was also voiced in the parliament, the Icelandic Ministry of Welfare reached an agreement with Icelandic Standards. The ÍST85 would be accessible free to the public for the next four years, with a possible four-year extension. ${ }^{31}$

\subsection{IMPLEMENTATION OF THE ÍST85}

ÍST85 can only be accessed free of charge in Icelandic. The English version of the ÍST85 is available, but if a company wants to review the ÍST85, they will have to purchase it from the Icelandic Standard's website for 12.339ISK (approx. $81 €$ ). ${ }^{32}$ While the purchase of the ÍST85 is for free or for a marginal price, the implementation of ÍST85 can be very costly, especially for small and medium enterprises (SMEs). ${ }^{33}$ According to one of the comments to the Equal Status Act, obtaining the formal review of an auditor and the certification can cost between 500,000 ISK and 700,000 ISK (3333€-4666 €) for a medium-sized company. ${ }^{34}$ This does not include costs incurred by the company itself in implementing ÍST85. According to a survey conducted by the Icelandic Prime Minister's Office in 2019 among the companies that had obtained ÍST85 before 30th April 2019, the total cost of implementation incurred by the companies (including certification) varied from a few hundred thousand ISK to around 4.000.000 ISK (approx. 26.666 €). 68\% of the companies and institutions that answered the survey stated that their costs were below 2.000.000 ISK (approx. 13.333€). ${ }^{35}$

the legislation by merely referring to the standard as ÍST85:2012 is insufficient. Icelandic Standards can revise the standard or repeal it and any attempts to restrict Icelandic Standards to do so would, in the associations view, impede the standard's development and counteract the its purpose. Icelandic Standards also point out, that it is common to revise standards every five years, meaning that a revision should have taken place in 2017. Icelandic Standards have yet not revised the standard. See Icelandic Standards comments available at: <www.althingi.is/altext/erindi/146/146-1156.pdf> accessed 30 March 2021. Icelandic Standards did not submit any comments to the new Equal Status Act.

${ }^{30}$ This was for example addressed by SA Confederation of Icelandic Enterprise, 'Comments to the Equal Status Act', (15 May 2017), 2 <https://www.althingi.is/altext/erindi/146/146-1359.pdf> accessed 30 March 2021.

31 The Ministry of Welfare and Icelandic Standards entered into a four-year agreement on 10 November 2017, with a possible four-year extension. As of 12 April 2021, the contract has not been extended.

32 It can be found at: <www.stadlar.is/stadlabudin/vara/?ProductName=IST-85-2012-e > accessed 13 April 2021.

33 The Icelandic Confederation of University Graduates, the Icelandic Federation of Trade, the Confederation of Icelandic Enterprises, the Icelandic Chamber of Commerce, and one private comment all mentioned the high costs that implementing the Standard would entail. See:

$<$ www.althingi.is/pdf/erindi_mals/?lthing=146\&malnr=437> accessed 13 March 2020. More generally on SMEs in public procurement see: M Trybus, M Andrecka, 'Favouring Small and Medium Sized Enterprises with Directive 2014/24/EU?' (2017) 3/2017 European Procurement and Public-Private Partnership Law Review 224. 34 'Comments made by the Confederation of Icelandic Enterprises' (15 May 2017)

<www.althingi.is/altext/erindi/146/146-1359.pdf> accessed 13 March 2020.

35 The Icelandic Prime Minister's Office, 'Survey of the implementation process of equal pay certification (Isk: Könnun á innleiðingarferli jafnlaunavottunar)', <www.stjornarradid.is/library/01--Frettatengt---myndirog-skrar/FOR/Fylgiskjol-i-

frett $/$ Jafnlaunavottun $\% 20 \mathrm{k} \% \mathrm{c} 3 \% \mathrm{~b} 6$ nnun $\% 20 \mathrm{ni} \% \mathrm{c} 3 \% \mathrm{~b} 0$ urst $\%$ c3 $\%$ b6 $\%$ c3\%b0ur $\% 2005.19$.pdf $>$ accessed 30 March 2021. Given the different times of implementation listed in table 1, these companies and institutions 
The implementation of the ÍST85 is also time-consuming. It takes between six months to two years, where $2 / 3$ of the survey respondents stated that they finished implementation within eighteen months. ${ }^{36}$ Given how time-consuming the implementation of the ÍST85 seems to be, the three years granted for a newly established company or a company that previously did not fall within the legislation's scope is reasonable and welcomed.

The laws making the ÍST85 mandatory have been introduced to impact the Icelandic market and Icelandic companies' behaviour. The legislator's intention has not been to provide Icelandic law with an extraterritorial character. While the focus and aim have been local, a point of criticism shall be given that neither the original Equal Rights Act nor the repealing act address how the law should apply to foreign companies having their presence on the Icelandic market. Whether they should be excluded from applicability IST85 or not, or it should be applicable in a limited or full form. The lack of express regulation introduces uncertainty and questions. This can be presented on an example of public procurement. Suppose ÍST85 is required in Icelandic public procurement terms. Such a requirement can be indirectly discriminatory to foreign companies, as it might place them at a competitive disadvantage compared to Icelandic companies that already operate in the market and have ÍST85. The potential restriction to the trade that IST85 can post is broader. That is why before turning more specifically to public procurement law, the authors investigate the relationship between EEA and EU law, how equal pay is regulated on the EU level and whether ÍST85 is a restriction to trade, and if so, is it justifiable.

\section{THE RELATIONSHIP BETWEEN THE EEA AND EU LAW}

The European Free Trade Association (EFTA) was founded in 1960, three years after the EU's predecessor, the European Economic Community (EEC). On 2nd May 1992, the EEA Agreement was signed. ${ }^{37}$ The Agreement between the EFTA States was followed by the Establishment of a Surveillance Authority and a Court of Justice. ${ }^{38}$ The agreement establishing the EEA is essentially an extension (with certain limitations) of the EU internal market to three of EFTA's Member States, namely Iceland, Norway, and Lichtenstein. Characterising the nature of the agreement, the EFTA court said in the Sveinbjörnsdottir case:

The EEA Agreement is an international treaty sui generis which contains a distinct legal order of its own. The EEA Agreement does not establish a customs union but an enhanced free trade area... The depth of integration of the EEA Agreement is less far-reaching than under the EC Treaty, but the scope and the objective of the

are most probably not SME's. As the legislation is relatively new and research on the topic is scarce, there is little known about how effective the mandatory ÍST85 is. However, a recent article, discusses the experience of managers regarding the effect of the ÍST85 on wage environment. The article suggests that managers experienced increased bureaucracy and displacement of decision-making power. See G Björg Hafsteinsdóttir et al, 'Behind Every System are People: Managers Experiences of the Effect of Equal Pay Certification on Wage Environment' in Icelandic Review of Politics and Administration 2020, Vol. 16, Issue 2, 261-284. (The article is in Icelandic].

36 ibid.

${ }^{37} \mathrm{~S}$ Norberg, M Johansson 'The History of the EEA agreement and the first twenty years of its existence' in C Baudenbacher (ed) The Handbook of EE A Law (Springer 2016), 4-5.

38 Agreement between the EFTA States on the Establishment of a Surveillance Authority and a Court of Justice [1994] OJ L344/82. 
EEA Agreement goes beyond what is usual for an agreement under public international law. ${ }^{39}$

EEA law and EU law are two separate legal orders, but since EEA law originates from EU law, they are largely identical in substance. ${ }^{40}$ The EEA Agreement aims to optimise the functioning of the EEA by creating homogeneity within EFTA and the EU. ${ }^{41}$ Article 1 of the EEA Agreement states that the four freedoms of the internal market must be upheld and also stipulates that mechanisms should be put in place to prevent distortion of competition within the market. ${ }^{42}$

The core principles of the EEA resemble existing principles in the EU. Aside from the principle of homogeneity, which is often regarded as the 'cornerstone of the EEA agreement', the Agreement also includes other principles such as proportionality, state liability, sincere cooperation, and equality. ${ }^{43}$ The principle of sincere cooperation (or the loyalty principle) is fundamental in practice. The principle emphasises that the members of the EEA Agreement: 'shall take all appropriate measures, whether general or particular, to ensure fulfilment of the obligations arising out of the agreement'. ${ }^{44}$ There are also general EU principles that are not applicable for the EEA, namely the principle of direct effect and EU law supremacy. The EFTA court has repeatedly stated that the two principles are not part of the EEA Agreement. ${ }^{45}$ This is also clearly established through Protocol 35 to the EEA Agreement, stating that homogeneity must be reached through national procedures. ${ }^{46}$ However, under particular circumstances, EU legislation can have an effect that amounts to having a direct effect. ${ }^{47}$

To fulfil the EEA Agreement's objectives, a two-pillar system was created where EFTA mirrored various EU institutions. The creation of the system was necessary because the EU legal framework does not allow non-Member States to participate in its institutions. The EFTA institutions' purpose is to uphold the homogeneity principle from the EEA Agreement by interpreting and similarly applying the rules as the corresponding EU authorities do when monitoring and enforcing the rules. ${ }^{48}$ Two central authorities within EFTA are the EFTA Surveillance Authority (ESA), ${ }^{49}$ which mirrors the European Commission (Commission), and the EFTA court, which mirrors the Court of Justice of the EU (CJEU). ${ }^{50}$ The EFTA court's primary competencies are threefold: a) to take action on

\footnotetext{
${ }^{39}$ Case E-9/97 Erla María Sveinbjornsdottir v Iceland [1998] EFTA Ct. Rep. 95, para 59.

40 Art 97(ff) EEA Agreement.

41 ibid Art. 1(1).

42 ibid Art. 1 (2).

43 P Hreinsson 'General Principles' in C Baudenbacher (ed) The Handbook of EE A Law (Springer 2016), 350356.

44 Art. 3 EEA Agreement.

${ }^{45}$ Hreinsson (n 43) 383.

46 Protocol 35 on the Implementation of EEA Rules.

${ }^{47}$ Case E-11/12 Beatrix Koch [2013] EFTA Ct. Rep. 272, paras 118-120.

${ }^{48} \mathrm{G}$ Baur, 'Decision-Making Procedure and Implementation of New Law' in C Baudenbacher (ed) The Handbook of EEA Law (Springer 2016), 47-49.

49 The competence for surveillance of alleged infringements lies with the Commission if the alleged infringement is committed by a contracting entity in the EU and with ESA if it is committed by a contracting entity in an EEA State.

50 Art.108(1-2) EEA Agreement. The most important judgments of the EFTA Court are summarised in C Baudenbacher, EFTA Court - Legal Framework and Case Law (2006), available at www.eftacourt.lu/default.asp?layout=article\&id=348 [Accessed 12 April 2021].
} 
the surveillance procedure regarding the EFTA states; b) to handle appeals concerning decisions taken by ESA; c) to settle disputes between two or more EFTA states. ${ }^{51}$

On the matter of hierarchy within the EEA, the EEA agreement does not stipulate that CJEU rulings regarding the internal market prevail over the EFTA court rulings. ${ }^{52}$ However, according to Article 6 of the EEA, the EFTA court is bound to interpret provisions of the EEA Agreement that are identical in substance to corresponding rules of the EU Treaties in conformity with the relevant CJEU rulings given prior to the date of signature of the EEA Agreement. When it comes to rulings given after that date, the EFTA court must pay due account to the principles laid down by the relevant rulings of the CJEU. ${ }^{53}$ In practice, the EFTA court's case law is largely based on the CJEU's jurisprudence. ${ }^{54}$ The EEA States' national courts will hardly refer questions to the EFTA court, which the CJEU has answered in the EU or EEA law context. ${ }^{55}$ At the same time, the EFTA court has, in several cases, departed from the CJEU's 'precedents' and created new ones within the EEA. ${ }^{56}$

\section{EQUAL PAY AND GENERAL EU LAW}

The EU/EEA internal market is a legal and economic system that is supported by a regulatory platform of social policy in areas where the Member States have chosen to act together to improve the quality of the working and social environment in the EU. ${ }^{57}$ This is confirmed in Article 3(3) of the TEU, which embraces the 'social market economy'. Moreover, equal pay has been a clear objective of EU law since the very beginning of the EEC. What is now Article 157 TFEU originated in 1957 as Article 119 of the Treaty of Rome. ${ }^{58}$ The French government strongly lobbied for the inclusion of Article 119 in the Treaty of Rome. Yet its reasons were not related to securing equal human rights for women but rather preserving fair competition. ${ }^{59}$ Namely, France wanted to prevent other countries signing the Treaty of Rome from undermining the French economy by using women as a cheap source of labour. However, while the original goal of Article 157 was solely economic, the CJEU soon confirmed that the provision had both an economic and a social aspect. In the Defrenne II case, the CJEU stated: '[Article 157] ... forms part of the social objectives of the Community, which is not merely an economic union, but is at the same time intended, by common action, to ensure social progress and seek the constant improvement of the

\footnotetext{
51 Art 110(2) EEA Agreement.

52 O Valsson, 'EFTA Court is not bound to make use of ECJ rulings', (Financial Times, 2017)

<www.ft.com/content/268fa1a2-ca2f-11e7-ab18-7a9fb7d6163e> accessed 12 April 2021.

53 Art 3(2) of the Agreement between the EFTA States on the establishment of a Surveillance Authority and a Court of Justice (SCA) [1994] OJ L 344/82.

${ }^{54} \mathrm{C}$ Baudenbacher, 'EFTA Court, the ECJ, and the Latter's Advocates General - a Tale of Judicial Dialogue' in A Arnull, P Eeckhout, and T Tridimas (eds) Continuity and Change in EU Law: Essays in Honour of Sir Francis Jacobs (Oxford Scholarship Online 2009), 91.

55 ibid 90.

${ }^{56}$ Ch Timmermans, 'Creative Homogeneity' in M Johansson et al (eds) Festschrift Sven Norberg (Bruylant; Brussels 2006) 471-484.

${ }^{57} \mathrm{~S}$ Weatherill, Law and V alues in the European Union (OUP 2016).

58 Treaty Establishing the European Economic Community (Treaty of Rome) (1957).

$59 \mathrm{~J}$ Gregory 'Harmonisation or Deregulation - Implementing Equal Pay Law in the European Union and the United Kingdom' (1997) 27 Victoria University Wellington Law Rev. 555, 556-557; P Craig and G de Burca, EU Law: Text, Cases and Materials (5th edn, OUP 2011) 858.
} 
living and working conditions of their peoples' ${ }^{90}$ Later jurisprudence also suggests that the economic aspect of Article 157 TFEU plays second fiddle to the societal aspect of the Article. In the case Deutsche Telekom v. Schröder, the CJEU points out that: '[the] right not to be discriminated against on the grounds of sex is one of the fundamental human rights whose observance the Court has a duty to ensure'. ${ }^{61}$

As presented in Article 157 TFEU, the principle of equal pay is laid out in greater detail in secondary law. Directive $75 / 117 / \mathrm{EEC}$ was the first legislation within the EEC on equal pay. ${ }^{62}$ It played a significant role because the earlier incarnation of Article 119 of the Treaty of Rome only covered the right to 'equal pay for equal work'. Directive 75/117/EEC broadened the scope to 'work to which equal value is attributed'. ${ }^{63}$ Article 157 TFEU now contains this broadened scope. The Recast Directive subsequently replaced directive 75/117/EEC. ${ }^{64}$ The Recast Directive intended to systemise the existing EU legislation in the field of equality and update it in light of the jurisprudence of the CJEU. ${ }^{65}$

Following the previous sections, it is clear that primary and secondary EU law establishes the legal principle - which we refer to as an EU equal pay standard - that women and men are entitled to equal pay for equal work or work of equal value and that discrimination of pay based on sex is prohibited.

\subsection{APPLICABILITY OF THE EU EQUAL PAY STANDARD IN ICELAND}

Article 69 of the EEA agreement reflects Article 119 of the Treaty of Rome, thereby binding the EEA states to provide equal pay for equal work. As the wording of the Article is taken from the Treaty of Rome, Article 69 only states that men and women should receive equal pay for equal work but does not include the expansion of the provision included in Article 157 TFEU stating that equal pay should be applied for work to which equal value is attributed. ${ }^{66}$ Annex XVIII to the EEA agreement includes a specific provision on how to implement Article 69. Per the Annex, through the EEA, Iceland was obliged to adopt various regulations and directives in the field of social policy, one of which was the Recast Directive. ${ }^{67}$

\footnotetext{
${ }^{60}$ Case C-43/75 Defrenne v Sabena EU:C:1976:56, para 10. The Court also found Article 157 TFEU to have direct effect, regardless of whether it had been implemented into national law, see para 42.

${ }^{61}$ Case C-50/96 Deutsche Telekom v. Schröder EU:C:2000:72, para 56.

62 Council Directive 75/117/EEC of 10 February 1975 on the approximation of the laws of the Member States relating to the application of the principle of equal pay for men and women [1975] OJ L 45/19, 19-20. 63 ibid Art. 1. See I Heide, 'Supranational Action Against Sex Discrimination: Equal Pay and Equal Treatment in the European Union' (1999) International Labour Review 381, 391.

${ }^{64}$ Recast Directive (n 16).

${ }^{65}$ Craig and de Burca (n 59) 874. One of these developments concerned the burden of proof: Art. 19 Recast Directive 'Member States shall take such measures as are necessary, in accordance with their national judicial systems, to ensure that, when persons who consider themselves wronged because the principle of equal treatment has not been applied to them establish, before a court or other competent authority, facts from which it may be presumed that there has been direct or indirect discrimination, it shall be for the respondent to prove that there has been no breach of the principle of equal treatment'. The principle of the shifting burden of proof stems from the Case 109/88 Danfoss EU:C:1989:383, para 14. In this case, the CJEU found that when an employer applies wage systems that are greatly lacking in transparency the burden of proof will shift from the employee to the employer.

${ }^{66}$ This is not surprising, though, since 'work to which equal value is attributed' was only added in the Treaty of Amsterdam in 1997, while the EEA Agreement is from 1992.

${ }^{67}$ See C Bernard, 'Social Policy Law' in C Baudenbacher (ed) The Handbook of EE A Law (Springer 2016) 816.
} 
Equality of pay is also regulated in Article 23 of the EU Charter of Fundamental Rights. ${ }^{68}$ Even though the EU Charter of Fundamental Rights is not legally binding for EEA countries, the EFTA court has pointed out that the EEA Agreement's provisions shall be interpreted in light of fundamental rights. ${ }^{69}$ The three EFTA countries that are parties to the EEA agreement have adopted the European Convention of Human Rights (ECHR). The EFTA court has found that the ECHR and judgements from the European Court of Human Rights are 'important sources for determining the scope of these rights'. ${ }^{70}$

The EU equal pay standard is applicable in Iceland. Consequently, the Icelandic ÍST85 can be viewed as an enforcement mechanism of the EU equal pay law. While substantively, the EU equal pay law and the ÍST85 afford the same rights, the procedural mechanisms in ÍST85 provide a higher level of effectiveness for equal pay. This is primarily because, under IST85, the burden of proof is by default shifted from the employee to the employer. To attain certification, an employer must prove the respect of equality of pay throughout the entire company. Under EU law, the burden of proof may shift solely when the employee can demonstrate facts from which it may be presumed that there has been direct or indirect discrimination, meaning that it is more difficult for the employee. ${ }^{71}$

In 2017 the Commission acknowledged that the gender pay gap is an ongoing issue within Europe and published an action plan to tackle this problem. ${ }^{72}$ Recently the Commission has also published the evaluation of the Recast Directive's principle of equal pay. ${ }^{73}$ Amongst several points of the evaluation, the Commission emphasised ${ }^{\circ}$ The need to improve the practical application of the reversed burden of proof ${ }^{74}$ This could be argued is already addressed under the ÍST85.

While from the perspective of equal pay law, the ÍST85 can be viewed as an enforcement mechanism of The EU equal pay standard. It is still necessary to analyse whether the application of ÍST85 to foreign companies constitutes a restriction to trade and, if so, if it is justifiable. The article further focuses on considerations arising from the provision of service by a foreign company (clear cross-border element) under a public contract in Iceland. We must, therefore, conduct a primary EU/EEA law analysis of ÍST85, viewed in the context of freedom to provide service.

\section{PRIMARY EU/EEA LAW ANALYSIS OF ÍST85}

The memorandum accompanying the establishment of ÍST85 as mandatory law states that Iceland is bound by Article 69 of the EEA agreement. It has also implemented the Recast Directive, where Article 4 lays out the right to equal pay. ${ }^{75}$ However, no reference is made to free movement laws, specifically Articles 36 (the equivalent of Art. 56 TFEU) and 11 (the equivalent of Art. 34 TFEU) of the EEA agreement regarding freedom to provide services

\footnotetext{
${ }^{68}$ Charter of Fundamental Rights of the European Union [2012] OJC326/391.

${ }^{69}$ Case E-2/03 Ásgeirsson [2003] EFTA Ct. Rep. 18, para 23.

70 ibid.

${ }^{71}$ Art. 19 Recast Directive (n 16).

${ }^{72}$ Communication from the Commission to the European Parliament, the Council and the European Economic and Social Committee COM (2017) 678 final.

${ }^{73}$ Commission, 'Evaluation of the relevant provisions in the Directive 2006/54/EC implementing the Treaty principle on 'equal pay for equal work or work of equal value' SWD (2020) 50 final.

74 ibid 68.

${ }^{75}$ Art. 69 of the EEA Agreement is reflected in Art. 157 of the TFEU.
} 
and goods within the EEA. This shall be noted as a point of criticism. ÍST85 as mandatory Icelandic law may constitute a market access barrier, and it seems that the legislator did not consider the implications of the standard to the internal market.

The guarantee of non-discriminatory and unrestricted market access constitutes the core of the internal market law. It is primarily achieved by enforcing the fundamental freedoms laid down in the EU Treaties. Article 56 and 57 TFEU outline the principles behind the free movement of services within the EU. The two articles are almost identical to Articles 36(1) and 37 of the EEA. Article 57 TFEU defines services as activities not governed by other freedoms that are provided for remuneration. The Article also notes a few primary examples of services, one of them being 'activities of a commercial character. ${ }^{76}$ The concept of the freedom to provide services is closely linked to the freedom of establishment found in Article 49 TFEU. The defining character of service is its temporary character. In the Gebard case, the CJEU stated: '[...] the temporary nature of the activities in question has to be determined in the light, not only of the duration of the provision of the service, but also of its regularity, periodicity or continuity. ${ }^{77}$ Thus, work containing an economic element conducted temporarily within another Member State constitutes services. Such services will be restricted in light of Articles 56 and 57 if a country has implemented: '[...] national rules which have the effect of making the provision of services between Member States more difficult than the provision of services purely within a Member State'. ${ }^{78}$

The CJEU has found that the temporary character of services can vary greatly on the basis of their nature and that services can be provided over an 'extended period, even over several years', especially when services are provided concerning the construction of infrastructure. ${ }^{79}$ The concept underpinning the freedom to provide services seemed to arise amid efforts to grant a service provider the freedom to travel to another Member State to conduct services unrestricted. ${ }^{80}$

Given this broad notion of services, a foreign company sending workers or employing people in Iceland to implement a public contract for an extended period is conducting services and would have to comply with the mandatory requirements of the Gender Equality Act. It is crucial to underline that the ÍST85 must be adopted for all company employees in question. ${ }^{81}$ This effectively means that if a company sends or employees $25+$ workers in Iceland to provide particular services for a period that exceeds a year, it would be covered by the requirement to adopt an equal pay system (ÍST85) for the whole company.

Iceland shall recognise professional qualifications or other requirements (eg standards) from the country of origin to be prima facie equivalent - the principle of mutual recognition as the foreign company may have implemented an equal pay system in its country of origin. Alternatively, the foreign company may fulfil the ÍST85 requirements through different

\footnotetext{
76 Art. 57(2)(c) TFEU.

${ }^{77}$ Case C-55/94 Reinhard Gebhard EU:C:1995:411, para 39.

${ }^{78}$ Case C-444/05 Aikaterini Stamatelaki EU:C:2007:231, para 25. On the effect of the national measure on the market in regard to free movement of goods, see Case 8/74 Dassonville EU:C:1974:82.

${ }^{79}$ Case C-215/01 Schnitzer EU:C:2003:662, para 30.

${ }^{80}$ See Case 33/74 Binsbergen EU:C:1974:131, para 10: 'The restrictions to be abolished pursuant to Articles 59 and 60 include all requirements imposed on the person providing the service by reason in particular of his nationality or of the fact that he does not habitually reside in the State where the service is provided, which do not apply to persons established within the national territory or which may prevent or otherwise obstruct the activities of the person providing the service'.

81 Art 4(1) ÍST 85:2012.
} 
means that Iceland shall recognise if those different means fulfil the same standard as ÍST85. Consequently, based on the EU mutual recognition principle, Iceland shall recognise supplier national certifications or mechanism of compliance with the equal pay law. ${ }^{82}$ Under such circumstances, the ÍST85 would not constitute a restriction of services in light of Article 36 EEA (56 TFEU).

If Iceland is not providing mutual recognition for various reasons, it is necessary to assess whether ÍST85 is discriminatory towards foreign companies. ÍST85 applies in a nondiscriminative manner to both Icelandic and foreign companies fulfilling the mandatory requirements of the Gender Equality Act. The act does not differentiate between services and establishment in this regard. Provided the criteria are fulfilled, the law applies. ${ }^{83}$ However, the CJEU has constituted that Article 56:

[...] requires the abolition of all restrictions on the freedom to provide services, even if those restrictions apply without distinction to national providers of services and to those from other Member States, when they are liable to prohibit, impede or render less advantageous the activities of a service provider established in another Member State where it lawfully provides similar services. ${ }^{84}$

Consequently, ÍST85 might be indirectly discriminatory toward foreign companies which would need to obtain the standard if they would like to provide services on the Icelandic market. Nevertheless, the existence of restrictions is not uncommon. EU case law establishes a broad spectrum of allowed restrictions, eg national degrees or qualifications: laws that require domestic qualifications for the access to certain professions indirectly discriminate against graduates of foreign universities; ${ }^{85}$ requirements for a service provider to have a permit, an approval, an assessment or to provide security to provide the service; ${ }^{86}$ restriction on bringing personnel or using brought along personnel, eg the requirement of work permits or minimum wages. ${ }^{87}$

\subsection{JUSTIFICATIONS}

If to conclude that the ÍST85 constitute a restriction on the freedom to provide services, it can be justified under specific circumstances. ${ }^{88}$ Namely, the EU law aids such indirect discriminatory restrictions by allowing them to be justified on overriding grounds of general

\footnotetext{
82 See Ch Janssens, The Principle of Mutual Recognition in EU Law (OUP 2013).

${ }^{83}$ It is specifically stated in Art. 4(1)(7) of Act 45/2007 on Posted Workers and Obligations of Foreign Service Providers that companies which post workers in Iceland cannot grant their workers lesser rights than are provided in Act 96/2000 on the Equal Rights of Men and Women. Act 96/2000 is the predecessor to the Equal Rights Act and the Gender Equality Act. Even though the Icelandic Posted Workers Act has not been updated in regard to that fact, its applicability is undisputed.

${ }^{84}$ Case C-42/07 Liga Portuguesa de Futebol Profissional and Bwin International Ltd v Departamento de Jogos da Santa Casa da Misericórdia de Lisboa EU:C:2009:519, para 51.

${ }^{85}$ Case 71/76 Thieffry EU:C:1977:65; Case 330/03 Colegio EU:C:2006:45; Case 345/08 Pesla EU:C:2009:771.

${ }^{86}$ Case 355/98 Commission vs Belgium EU:C:2000:113, para 35; Case 9/16 Unibet International EU:C:2017:491, para 34; Case 279/00 Commission vs Italy EU:C:2002:89, paras $31 \mathrm{f}$.

${ }^{87}$ Case 113/89 Rush Portuguesa EU:C:1990:142, para 12; Case 115/14 RegioPost EU:C:2015:760, para 69.

88 Art. 62 TFEU and Art. 39 of EEA Agreement.
} 
interest. ${ }^{89}$ These justifications include public policy, public security, or public health, though this list is not exhaustive. ${ }^{90}$ The CJEU has developed a justification test concerning services which greatly resembles the Cassis de Dijon test regarding the free movement of goods. ${ }^{91}$ It is generally referred to as a 'mandatory requirements' test for goods, whereas regarding services, the term 'objective justification' test has been used. ${ }^{92}$

The three-step justification test was laid out in Van Binsbergen case. ${ }^{93}$ The restriction must be: a) due to a legitimate interest, b) equally applicable to persons established within the state, non-discriminatory, and c) proportionate. ${ }^{94} \mathrm{~A}$ fourth requirement not named in the $V$ an Binsbergen case has been referred to in the following case law concerning justification, though it has received less attention from the CJEU. This requirement is that the restrictive measure should respect fundamental rights. ${ }^{95}$ It was clearly stated in the Carpenter case that fundamental rights apply. ${ }^{96}$ Overall, via this test process, the CJEU has found inter alia that the protection of workers may be an objective justification under the test. ${ }^{97}$ This is to be understood positively as equal pay standard is perceived as ultimately protecting workers rights. In the following paragraphs, the authors will analyse whether ÍST85 passes the test of 'objective justification'.

Firstly, regarding pursuing a legitimate aim, establishing equal pay between men and women would be regarded as such within EU law. As noted in section 3, the concept of equal pay has been a part of EU law since its origin. Secondly, concerning the fact that the restriction should respect fundamental rights, it is clear that ÍST85 is applied to achieve equal pay between men and women, which is considered a fundamental right within Article 21 of the Charter of Fundamental Rights. ${ }^{8}$ Thirdly, ÍST85 applies in a non-discriminatory manner to all (foreign and domestic) companies covered by the scope of the Gender Equality Act. While one might point out that ÍST85 is freely accessible in Icelandic, whereas the English version must be purchased, given the costs linked to the implementation of the ÍST85, the value of a service provision requiring a foreign company to hire or post at least 25 staff to Iceland, the price of purchasing the ÍST85 is regarded as marginal. Therefore, not having discriminatory character.

The 'objective justification' test also necessitates applying the proportionality principle. The premise is to review whether the rule in question is appropriate to reach the rule's aim and whether any less restrictive measures were available to reach the same goal. ${ }^{99}$ Iceland adoption of progressive legislation that could be argued enforces the EU equal pay law shall not be deemed disproportionate compared to less progressive legislation of the same nature

\footnotetext{
${ }^{89}$ CJEU rarely makes a clear distinction between indirect discrimination and non-discriminatory hindrances, see Case 438/08 Commission vs. Portugal EU:C:2009:651.

${ }^{90}$ Art 62 TFEU. See also Gebhard (n 77) para 39. If present, the restrictions may be justified under four conditions. As listed in the Gebhard case: 'they must be applied in a non-discriminatory manner, they must be justified by imperative requirements in the general interest; they must be suitable for securing the attainment of the objective which they pursue; and they must not go beyond what is necessary in order to attain it'.

${ }^{91}$ Case 120/78 Cassis de Dijon EU:C:1979:42.

92 Craig and de Burca, (n 59) 800.

${ }^{93}$ See Case 33/74 V an Binsberger EU:C:1974:131.

${ }^{94}$ Craig and de Burca, (n 59) 801-802.

95 ibid 802.

${ }^{96}$ Case C-60/00 Mary Carpenter EU:C:2002:434, paras 38-39.

${ }_{97}$ Case 341/05 Laval EU:C:2007:809, para 107.

${ }_{98}$ Charter of Fundamental Rights (n 68).

${ }^{99}$ Craig and de Burca (n 59) 801.
} 
within the other Member States. ${ }^{100}$ Particularly as the gender pay gap still exists (at least 5.6\%) and Iceland's previous less restrictive measures have not been successful in closing this gap. However, the potential extraterritorial effect ÍST85 cannot be regarded as necessary to reach that goal. This can be seen if the Gender Equality Act's rules - making ÍST85 mandatory are to be interpreted as requiring the foreign company to adopt ÍST85 on a company-wide basis (much of which falls outside Icelandic jurisdiction) simply to provide services in Iceland for a limited period. As ÍST85 is directed to the Icelandic market, the legislation will reach that goal regardless of whether a foreign company situated within the EEA adopts ÍST85 company-wide or only adopts it for its employees providing services in Iceland.

Applying the proportionality principle does not result automatically in a finding that ÍST85 is breaching Articles 36(1) and 37 of the EEA. Rather, it requires the contracting authorities and eventually Icelandic courts to interpret the law's scope of applicability, making ÍST85 mandatory to foreign companies employing 25+ workers in Iceland. As Advocate general Wathelet clearly indicated in a case concerning the procurement remedies directives,

The principle that national law must be interpreted in conformity with EU law requires national courts to do whatever lies within their jurisdiction, taking the whole body of domestic law into consideration and applying the interpretative methods recognised by domestic law, with a view to ensuring that Directive 89/665 is fully effective and achieving an outcome consistent with the objective pursued by it. ${ }^{101}$

Consequently, a better consistent interpretation of the Icelandic law is to interpret the rules as applicable solely to the part of the foreign company operating on the Icelandic market as if otherwise the ÍST85 would be deemed potentially unproportioned. Further, the Gender Equality Act's rules applicable to newly established companies shall be extended to foreign companies. Namely, a newly established company (or a company whose recent change of circumstances triggers the applicability of ÍST85) has three years to implement the ÍST85. ${ }^{102}$ Therefore, it would be questionable and unproportioned to require a foreign company providing services for a shorter time to implement the IST85. The standard should be solely required from the companies operating on the Icelandic market for longer than the mentioned three-year period. If the standard is not implemented within the three years, the company can be subjected to fines. This concludes that the ÍST85 shall not be applied automatically to the foreign company entering the Icelandic market. It also would mean that ÍST85 shall not apply to a foreign company providing short-term services in Iceland- up to three years.

Conclusively, provided that the principles of mutual recognition and suggested consistent interpretation of ÍST85 law are complied with, IST85 can be read and applied in line with Articles 36(1) and 37 of the EEA.

\footnotetext{
100 Case C-384/93 Alpine Investments BV v Minister van Financiën EU:C:1995:126, para 51.

101 Case C-689/13 Puligienica Facility Esco SpA EU:C:2015:263, para 59.

102 The memorandum to Art. 7 the Gender Equality Act, 33-34.
} 


\section{EU PUBLIC PROCUREMENT LAW}

Applying ÍST85 through public procurement could be beneficial for achieving the equal pay goal in Iceland due to the large scale of public procurement. In Iceland, it amounts to more than 202 billion ISK each year. Public procurement can incentivise the private market to speed up the uptake of ÍST85 if the standard is required in public tenders. To analyse whether public procurement in this case can be used as a policy tool, it is necessary to assess whether the ÍST85 can be applied under EU public procurement secondary law. As a member of the EEA, Iceland has implemented the EU Public Procurement regime from 2014 into its national law. ${ }^{103}$ Therefore, Icelandic public procurement legislation is harmonised with the applicable EU legislation. ${ }^{104}$

Throughout the last decade, the EU procurement regime has increasingly recognised social considerations in public procurement. ${ }^{105}$ However, earlier endeavours were not easy. Social considerations have been often - and still are - viewed through a negative lens. On the one hand, they are deemed as considerations contradictory to the economic objectives of the EU procurement system and providing a smokescreen for preferential treatment. On the other hand, they are considered too burdensome on contracting authorities, limiting their flexibility and requiring a disproportionate amount of resources to implement them. This tension is evident in the fact that out of 253 amendments tabled by the EU Parliament (mostly from a social protection angle), the Council and the Commission rejected most of these when modernising the EU procurement directives. ${ }^{106}$

In the Directive 2014/24/EU, social issues are clearly supported, and their importance is given greater emphasis, thereby lowering, to a certain extent, the regulatory risks attached to these issues under the previous directives. ${ }^{107}$ Social considerations can be part of the procurement process as long as procurement rules and principles (transparency, nondiscrimination, equality, and proportionality and open competition) are respected.

It follows from Article 42 Directive 2014/24/EU on the technical specification as well as from the case law, eg Dutch coffee case that social consideration, such as equal pay, shall not be considered as part of a technical specification as this focuses on what contracting authorities buy rather than from whom they buy or how the contract is performed. ${ }^{108}$ However, the Directive 2014/24/EU introduces the so-called sustainability principle in Article 18(2). Member States are to ensure compliance with the mandatory EU, international and national

\footnotetext{
103 Act no. 120/2016 on Public Procurement.

104 The remedies are provided through the possibility to complain to Public Procurement Complaints Commission. In 2019, the Complaints Commission issued 56 rulings on the basis of complaints and in 2018 it issued 40 such rulings.

${ }^{105}$ Cases 346/06 Rüffert EU:C:2008:189; Case 549/13 Bundesdruckerei EU:C:2014:2235; and RegioPost (n 87). 106 See: M Andrecka and K Peterkova Mitkidis, 'Sustainability Requirements in EU Public and Private Procurement-A Right or an Obligation' (2017) 1 Nordic Journal of Commercial Law 55.

107 Switzerland which is not an EU Member State also supports equal pay considerations in public procurement. Namely, it introduced controls in relation with public procurements to eliminate gender pay discrimination. Art. 8(1)(c) Federal Act on Public Procurement: 'The following principles shall be respected in awarding public contracts: [...] (c) Contracts shall only be awarded to suppliers that guarantee equal treatment of men and women in respect of pay for workers performing services in Switzerland'. Art. 6, para 4, Ordinance on Public Procurement 'The awarding authority may call for checks in respect of equal treatment of women and men. The task of conducting such checks may be assigned to federal, cantonal or local authority gender equality offices'.

108 Case C-368/10 Commission v Netherlands (Dutch Coffee) EU:C:2012:284.
} 
laws - eg equal pay - under their tenders and public contracts. ${ }^{109}$ This means that particularly during the selection stage of public procurement, a contracting authority has a right or even an obligation to excluded ÍST85 non-compliant bidder from the tender under specific circumstances. ${ }^{110}$ Alternatively, ÍST85 may be analysed as a special condition for contract performance as a standard to be complied with when the contract is performed. These two phases will be further analysed below.

\subsection{COMPLIANCE WITH MANDATORY LAWS AND SELECTING COMPLIANT BIDDER}

The selection stage of a public procurement process is when contracting authorities focus on who the bidder is and if they comply with the applicable laws. For this reason, it seems most appropriate for a contracting authority to apply the requirement of equal pay standard (ÍST85) as a part of a qualification stage. ${ }^{111}$ Specifically applicable for contracting authorities is Article 18(2) Directive 2014/24/EU, which reads:

Member States shall take appropriate measures to ensure that in the performance of public contracts economic operators comply with applicable obligations in the fields of environmental, social and labour law established by Union law, national law, collective agreements or by the international environmental, social and labour law provisions listed in Annex X. ${ }^{112}$

Referring to Article 18(2), contracting authorities may apply ÍST85 at the exclusion phase of the qualification stage in the procurement proceedings. Contracting authorities also have a general right not to award a contract in case of non-compliance with Article 18(2), an obligation to reject an abnormally low tender in case of non-compliance with Article 18(2) and are to require subcontractors' compliance with Article 18(2). ${ }^{113}$

\footnotetext{
${ }^{109}$ Case C-395/18 Tim SpA EU:C:2020:58, para 38: 'EU legislature sought to establish [Art.18.2] as a principle, like the other principles referred to in paragraph 1 of that article [...]. It follows that such a requirement constitutes, in the general scheme of that Directive, a cardinal value with which the Member States must ensure compliance pursuant to the wording of Article 18(2) of that Directive'. Listen to: M Andhov, W Janssen, 'Episode \#8: Art. 18(2) and the Tim case: a sustainability principle?' (Bestek - the Public Procurement Podcast) <www.bestekpodcast.com> accessed on 15 April 2021.

110 The obligation will follow from interpretation of Art. 18(2) as a procurement principle. Whether this character can be given this Article is still unclear. See Case C-395/18 Tim SpA (n 109); Andhov (n 6); Andhov, Janssen (n 109); M Andhov, 'Commentary to Article 18(2)' in R Caranta, A Sanchez-Graells (eds) Commentary of the Public Procurement Directive (2014/24/EU) (Edward Elgar 2021).

111 Art. 57(4)(a) Directive 2014/24/EU.

112 Art. 18(2) as one of the pro sustainable provisions does not include the requirement of the considered laws to be 'link to the subject matter of the contract'. In this context Art.19(5) (a) Scottish Public Contract Regulation narrows down the application of Art 18(2) as it states it always shall be linked to the subject matter' which might pose challenges in application of equal pay standard similar too ÍST85 in the Scottish procurement.

113 Arts. 56(1), 69(3), 71(1) Directive/2014/24/EU. On issues of abnormally low tender, see Case C-599/10 SAG ELV Slovensko EU:C:2012:191; Joined Cases C-285/99 and C-286/99 Lombardini and Mantovani v ANAS EU:C:2001:640; Joined Cases C-147/06 and C-148/06 SECAP and Santorso v Comune di Torino EU:C:2008:277.
} 
The inclusion of Article 18(2) is perceived as an undeniable milestone in fighting social dumping in the public contracts market. ${ }^{114}$ The provision is seen as an essential tool that can ensure compliance with social laws such as, eg equal pay in the context of public procurement. ${ }^{115}$

It follows from section 3 of this article that equal pay is an EU equal pay standard regulated by both primary and secondary EU law. Also, Article 18(2) refers to Annex X in which mentioned is international labour law, namely ILO Convention on Equal Remuneration no. 100, which in Article 2 states:

'1. Each Member shall, by means appropriate to the methods in operation for determining rates of remuneration, promote and, in so far as is consistent with such methods, ensure the application to all workers of the principle of equal remuneration for men and women workers for work of equal value.

2. This principle may be applied by means of

a) national laws or regulations;

b) legally established or recognised machinery for wage determination;

c) collective agreements between employers and workers; or

d) a combination of these various means'. ${ }^{116}$

Consequently, equality of pay is established on all three legal levels and is included in the scope of Article 18(2). ÍST85 does not on its own establish new law or higher standard of equal pay. Rather it represents an enforcement mechanism for European and international law. Consequently, ÍST85 constitutes proof for trifecta compliance with at the same time EU law, international law and national equal pay law.

\section{1 [a] Means of proof of equal pay law compliance}

Based on Article 60 Directive 2014/24/EU, the Icelandic contracting authority is obliged to accept measures equivalent to the ÍST85 standard as proofs of foreign companies' compliance with equal pay requirement. This means that foreign companies will be able to demonstrate their compliance by providing similar standards obtained at their jurisdiction. In case a country in question does not issue such documents or certificates, they might be replaced by

'a declaration on oath or, in Member States or countries where there is no provision for declarations on oath, by a solemn declaration made by the person concerned

\footnotetext{
${ }^{114}$ Art. 18(2) is referred to as 'mandatory social considerations' see European Trade Union Confederation (ETUC), 'New EU framework on public procurement. ETUC key points for the transposition of Directive 2014/24/EU' (2015) 9 <www.etuc.org/sites/default/files/publication/files/ces-

brochure_transpo_edited_03.pdf $>$ accessed 15 April 2021; on 'mandatory social clause' see A Semple, 'Living Wages in Public Contracts: Impact of the RegioPost Judgment and the Proposed Revisions to the Posted Workers Directive' in A Sánchez Graells (ed), Smart Public Procurement and Labour Standards (Hart Publishing 2018) 83.

115 Art. 18(2) could - with several important changes - be seen as a continuation of Art. 27 of Directive 2004/18/EC on obligations relating to taxes, environmental protection, employment protection provisions, and working conditions.

116 Memorandum to Amendment Act no. 56/2017 introducing ÍST85 as a mandatory law reference the equal pay obligations from ILO Convention no. 100, 5 and 18.
} 
before a competent judicial or administrative authority, a notary or a competent professional or trade body, in the Member State or country of origin or in the Member State or country where the economic operator is established'. ${ }^{117}$

Theoretically, it is also possible to use a European standard as a means of proof. ${ }^{118}$ However, currently, there is available no European standard on equal pay. Article 62 solely refers to quality assurance and environmental management standards. The only European standard which considers social aspects is the one on accessibility for disabled persons. ${ }^{119}$

\section{$6.1[b]$ The relationship between primary and secondary law}

The application of EU secondary law alone would lend by itself to more permissive as to the sphere of application of ÍST85 than EU primary law, including by recognising its extraterritorial effect. This is hardly surprising since exclusion is about the reliability of a tenderer. An economic operator having paid bribes or being involved in collusion in its own jurisdiction does not become suddenly reliable only because it is tendering in another Member State. There is no reason why the breach of a mandatory social standard such as equal pay should be treated differently.

The fact remains that the TFEU has a higher standing in the hierarchy of EU law than (secondary) public procurement law. Therefore, the traditional rigid application of the proportionality principle developed in the context of restrictions to the freedom to provide services should, in principle, prevail. However, as highlighted, for instance, in Arblade case, the case law on those specific restrictions applies so far as 'there is no harmonisation in the field'. ${ }^{120}$

The case can be made that, read together, the Recast Directive and the Directive 2014/24/EU do indeed harmonise the field. They explicitly allow the Member States and their contracting authorities to exclude economic operators that are non-reliable because they do not comply with equal pay legislation. ÍST85 is a specific means of proof of such compliance devised by the Icelandic legislator. As discussed above, in circumstances where the country of the company' origin does not issue documents or certificates proving compliance with equal pay laws, they might be replaced by a declaration or oath. Hardly something to lament the breach of internal market principles. It might be even very little. The value and reliability of such declarations compared to the extensive requirements that must be met to obtain the ÍST85 standard is questionable. Therefore, an outstanding question is whether an Icelandic contracting authority could not accept proof in the form of, eg an equivalence declaration but require that the bidder have the ÍST85 standard. Three scenarios must be recognised:

1) The foreign company that employs $25+$ employees enters the Icelandic market for the first time. The public contract for which it bids is short term - under three years. Alternatively, the foreign company has been on the Icelandic market providing services

\footnotetext{
117 Art. 60(2)(b) Directive 2014/24/EU.

118 ibid Art. 62.

${ }^{119}$ European Committee for Standardisation available at:

<www.standards.cen.eu/dyn/www/f?p=CENWEB:105> accessed 3 March 2021.

120 Joined cases C-369/96 and C-376/96 Arblade EU:C:1999:575, para 34.
} 
for less than three years. Under such circumstances, the contracting authority shall accept the self-declaration and cannot insist on obtaining the ÍST85 standard that would violate the proportionality principle.

2) The foreign company that employs $25+$ employees has been on the Icelandic market for more than three years. Under such circumstances, it is justifiable in our opinion for the contracting authority to require ÍST85 standard as mandatory law in Iceland. The three-year grace period applicable to new Icelandic companies and companies whose recent change of circumstances triggers the applicability of ÍST85 is over.

3) The foreign company that employs $25+$ employees enters the Icelandic market for the first time. The public contract for which it bids is a long term contract - over three years. Under such circumstances, the contracting authority shall accept the selfdeclaration and cannot insist on obtaining the ÍST85 standard that would violate the proportionality principle. However, the contracting authority might potentially oblige the bidder within the contract performance clause to obtain the ÍST85 within three years.

\subsection{SPECIAL CONTRACT PERFORMANCE CONDITIONS}

As remarked above, compliance with ÍST85 could - alternatively - be required as a special contract performance condition. Contracting authorities may establish special conditions relating to the performance of a public contract. Such conditions can be 'social or employment-related considerations'. ${ }^{121}$ Recital 97 expressly refer to the contract performance condition as potential means for the introduction of measures ensuring equality of man and woman: 'Contract performance conditions might also be intended to favour the implementation of measures for the promotion of equality of women and men at work, the increased participation of women in the labour market and the reconciliation of work and private life'.

Any special contract conditions must be indicated in the call for competition or the procurement documents. Also, it must be 'link to the subject-matter of the contract' (LtSMoC). The latter requirement is a new addition to the provision on contract performance conditions, which was not present under the old version of the provision. ${ }^{122}$ Consequently, to assess the possibility of applying the ÍST85 standard as a special contract condition in the procurement procedure, it is necessary to examine whether ÍST85 can be linked to the subject matter' of the public contract.

\section{2 [a] Link to the subject-matter - Limitation for ÍST85 application}

The CJEU developed the LtSMoC concept in its case law regarding award criteria for public contracts. Starting with the Concordia case, the court allowed a public entity to use environmental considerations, namely the emissions of nitrogen oxide and noise, amongst the criteria for the contract award. The CJEU established that: '[W] here the contracting authority decides to award a contract ... it may take criteria relating to the preservation of the environment into consideration, provided that they are linked to the subject matter of

121 Art. 70 Directive 2014/24/EU.

122 Art. 26 Directive 2004/18/EC. 
the contract'. ${ }^{123}$ These criteria cannot confer an unrestricted freedom of choice on the contracting authority. They must be explicitly mentioned in the contract notice or tender documents and must comply with the fundamental EU Treaties principles, particularly nondiscrimination.

During the last decade, the LtSMoC concept progressed. Particularly in the Dutch Coffee case, the $\mathrm{LtSMoC}$ is expanded by underlining that there is no requirement for award criteria to relate to a core characteristic of a product or something which alters its material substance. ${ }^{124}$ Specific processes of production, and the provision of trade or a specific process for another stage of their life-cycle, even where such factors do not form part of their material substance, are considered LtSMoC. ${ }^{125}$

Currently, the concept is applied at the public procurement award stage and contract performance conditions where the social concerns might be considered. ${ }^{126}$ Still, they must be connected to the contract that is to be awarded - meaning that the contract performance condition must be directly linked to the activities carried out under the contract and nothing beyond that. This line of argumentation is supported by the Recital 97 of the Directive 2014/24/EU, which states:

However, the condition of a link with the subject-matter of the contract excludes criteria and conditions relating to general corporate policy, which cannot be considered as a factor characterising the specific process of production or provision of the purchased works, supplies or services. Contracting authorities should hence not be allowed to require tenderers to have a certain corporate social or environmental responsibility policy in place.

Thus, the social requirements must relate to the goods, services, or works that are being purchased. They cannot concern matters which fall outside the scope of the procurement relationship and the public contract itself. With the principles of non-discrimination and proportionality, the $\mathrm{LtSMoC}$ creates limitations when applying social considerations such as those underpinning ÍST85 in public procurement.

The concept of LtSMoC makes it impossible to include IST85 standards to the extent that it addresses matters beyond the specific subject matter of a public contract. It could be argued that a contracting authority may require ÍST85 solely regarding the scope of its application to the tendered public contract. However, this is problematic since ÍST85 states explicitly that for a company to implement the standard, it would have to implement an equal wage management system, where all (emphasis added) positions within a company are defined. ${ }^{127}$ Consequently, the contracting authority shall define the performance conditions by reference to the relevant (ie LtSMoC) specifications of the ÍST85, highlighting that after the three year grace period required will be ÍST85 as a means of proof of compliance. ${ }^{128}$ This way, the contract performance clause will provide an additional layer of contractual

\footnotetext{
123 Case C-513/99 Concordia Bus Finland EU:C:2002:495, para 64.

${ }^{124}$ Case Dutch Coffee (n 108).

125 Art. 67 Directive 2014/24/EU.

${ }^{126}$ Case Dutch Coffee (n 108).

127 Art. 4(1) IST85:2012.

128 See related information on application of labels in public procurement: Andhov, 'Commentary to Article 43' in Caranta and Sanchez-Graells (n 110).
} 
enforcement of mandatory legal provisions after a period of three years. ${ }^{129}$ Alternatively, to make it possible to apply ÍST85 within public procurement contract performance conditions, the ÍST85 standard issuing body would have to be more flexible and predict options of issuing the standard for a specific scope that would cover the public contract.

\section{THE APPLICATION OF ÍST85 TO THE POSTED WORKERS DIRECTIVE}

In a situation where an Icelandic contracting authority procures service delivery in Iceland, the EU's Posted Workers Directive may become applicable. ${ }^{130}$ We might envisage a scenario where a foreign company from the EU is awarded the contract and sends its employees to Iceland to perform the public service contract. The Posted Workers Directive would protect these workers.

Based on the EEA Agreement, Iceland had to implement the Posted Workers Directive into Icelandic law. According to the Icelandic Posted Workers Act, the terms of the Act on Equal Status and Equal Rights of Women and Men shall apply to posted workers in Iceland. Therefore, implementing the ÍST85 becomes mandatory for a company which, has been present on the Icelandic market for over three years and posts its workers to Iceland if there are $25+$ workers annually working in Iceland.

In recent years, public and academic attention has been brought to bear on issues of labour law and social protection of workers as a special condition in public procurement contracts due to CJEU rulings in three cases: Rüffert, ${ }^{131}$ Bundersdruckerei, ${ }^{132}$ and RegioPost. ${ }^{133}$ Though materially different, all three cases address a situation in which a minimum wage requirement was included as a special requirement in a public contract where the bidders would not be awarded the contract without fulfilling the minimum wage criteria.

It is clear from the principles laid out in the three judgements that for contract performance conditions, such as a minimum wage, to fulfil the standards of Article 56 TFEU on the freedom of services, it would have to be a part of universally applicable law or collective agreement. ${ }^{134}$ Two of the cases, Rüffert and Bundesdruckerei, also clarify that the requirement in question must apply to both public and private contacts. In the context of ÍST85, this is not an issue since the scope of the legislation covers both public and private companies. The law following from the mandatory ÍST85 standard is universally applicable. There is also a clear objective justification for the legislation, as outlined earlier.

It is also worth considering a scenario in which a foreign company is awarded a public contract for service provision from a distance, such as online services. This undertaking would not by law have to comply with Icelandic legislation, and consequently, the mandatory scope of ÍST85 would not be applicable in such a case. It follows from the Bundesdruckerei case, where CJEU found it disproportionate to require a Polish subcontractor to pay its employees in Poland a minimum wage as defined in Germany. The fixed minimum wage

\footnotetext{
129 Andhov, 'Commentary to Article 70' (n 110).

${ }^{130}$ Directive 97/71/EC of the European Parliament and of the Council of 16 December 1996 concerning the posting of workers in the framework of the provision of services [1996] OJ L 18/1.

131 Rüffert (n 105).

132 Bundesdruckerei (n 105).

133 RegioPost (n 87).

134 ibid. Article 3(1) of the Posted Workers Directive.
} 
imposed on the Polish subcontractor had no relation to the cost of living in Poland and went further than what was needed to ensure the original objective of employee protection. The court assessed that the requirement would also deprive the Polish companies of their competitive advantage. ${ }^{135}$ Therefore, it is highly likely that similar argumentation would apply in a case where ÍST85 is required in a tender where the services would be fulfilled from a distance.

\section{CONCLUSIONS}

While Iceland is a small market, the country is undoubtedly a pioneer in addressing the pay gap between women and men through a law requiring companies to obtain ÍST85 - equality of pay standard. The preceding analysis may prove valuable to any Member State considering the introduction of similar legislation and approach. This will, after all, require detailed scrutiny of the critical issues and red flags that must be addressed. Our analysis is a useful contribution to understanding this type of legislation and public procurement processes.

The ÍST85 has been developed to apply locally. However, it has its effects on foreign companies wishing to provide services in Iceland. The article concludes that ÍST85 will not constitute a restriction to inter-state trade when the principle of mutual recognition is applied, and the equivalent measure (certifications, labels) from foreign companies' national jurisdiction would be accepted. If not, IST 85 may constitute a barrier to the inter-State provision of services, but it is potentially justifiable based on the CJEU's test. This stems from the fact that ÍST85 is pursuing a legitimate interest, namely the equality of pay between women and men, which is a fundamental right and one of the EU values most closely connected to the EU's aim of pursuing a 'social market economy'. At the same time, ÍST85 applies in an equal and non-discriminatory manner to all.

The uncertainty is whether the ÍST85 is proportionate, particularly due to its potential extraterritorial effect, which is not necessary for reaching the goal of closing the gender pay gap in Iceland. In the authors' opinion, the proportionality of the measure is ensured through consistent interpretation of the ÍST85. It would require extending the provisions granting a grace period of three years to newly established companies (or companies whose recent change of circumstances triggers the applicability of ÍST85) to foreign companies.

ÍST85 has not been designed with the purpose to apply to public procurements. Therefore, its application post certain challenges. EU public procurement directives allow the inclusion of social considerations in public tenders. Though, their application is limited by specific procurement objectives and provisions. Mainly because aspects such as equal pay relate to who the bidder is, while the procurement provisions mainly focus on what it is that contracting authorities are buying. However, the Directive 2014/24/EU introduces a new procurement principle in Article 18(2). The latter in its scope includes the requirement of compliance with mandatory, amongst others, equal pay laws.

It is concluded that ÍST85 does not introduce a new law on equal pay but rather enforces ILO convention no. 100, EU Treaties and Recast Directive, and Icelandic national law on equal pay. It constitutes a mean of proof of equal pay compliance. Contracting authorities shall allow equivalent proofs in the form of similar standard or certification

135 Rüffert (n 105) para 32. 
obtained in a different jurisdiction. A declaration of an economic operator shall suffice in special circumstances - particularly within the first three years of operating on the Icelandic market. In the authors' opinion, the mandatory law of the land that is a requirement of obtaining ÍST85 as means of proof rather than accepting, eg solemn declaration, shall apply after the foreign company which employs $25+$ employees is present on the Icelandic market for more than three years.

The application of ÍST85 through other provisions of public procurement pose some challenges. This stems primarily from the scope of the ÍST85 requiring company-wide applicability. EU public procurement law is solely interested in regulating the procurement relationship (the part of the company that will deliver the public contract). Anything beyond this risks categorisation as not $L t S M o C$. This would render the inclusion of ISTT85 as a special contract condition within the three-year grace period non-compliant with EU public procurement rules. Unless the certification body interpreted its rules flexibly and it would be possible to obtain the ÍST85 for specific scope covering the public contract solely.

The practical solution to the above challenge is for a large foreign company to establish a special purpose vehicle (SPV) to deliver the public contract. The SPV potentially would not trigger the applicability of ÍST85 (too few employees), or its scope would reflect what is necessary to deliver a public contract.

Finally, addressing this issue through public procurement law alone will not suffice. In practice, it can play a solely supportive role. ÍST85 must be reinforced through as many instruments as possible. Labour law, contract law, anti-discrimination law, corporate governance, and public opinion must work in concert with public procurement law if equal pay enforcement is to be actualised. 


\section{LIST OF REFERENCES}

Andhov M, 'Contracting authorities and strategic goals of public procurement - a relationship defined by discretion?' in S Bogojevic, X Groussot, J Hettne (eds.) Discretion in EU Procurement Law (Hart Publishing, 2019)

DOI https://doi.org/10.5040/9781509919512.ch-006

Andhov M, Janssen W, Episode \#8,'Art. 18(2) and the Tim case: a sustainability principle? 'in Bestek - the Public Procurement Podcast, available at: www.bestekpodcast.com

Andrecka M and Peterkova Mitkidis K, 'Sustainability Requirements in EU Public and Private Procurement-A Right or an Obligation' [2017] Nordic Journal of Commercial Law, 55

DOI: https://doi.org/10.5278/ojs.njcl.v0i1.1982

Baudenbacher C, EFTA Court - Legal Framework and Case Law (2006), available at www.eftacourt.lu/default.asp?layout $=$ article\&id $=348$

Baudenbacher C, 'EFTA Court, the ECJ, and the Latter's Advocates General - a Tale of Judicial Dialogue' in A Arnull, P Eeckhout, and T Tridimas (eds.) Continuity and Change in EU Law: Essays in Honour of Sir Francis Jacobs (Oxford Scholarship Online: January 2009) 91

DOI: https://doi.org/10.1093/acprof:oso/9780199219032.001.0001

Baur G, 'Decision-Making Procedure and Implementation of New Law' in C Baudenbacher (ed.) The Handbook of EEA Law (Springer, 2016)

DOI https://doi.org/10.1007/978-3-319-24343-6 2

Bernard C, 'Social Policy Law' in C Baudenbacher (ed.) The Handbook of EEA Law (Springer, 2016)

DOI: https://doi.org/10.1007/978-3-319-24343-6 37

Björg Hafsteinsdóttir G et al, 'Behind Every System are People: Managers Experiences of the Effect of Equal Pay Certification on Wage Environment' in Icelandic Review of Politics and Administration 2020, Vol. 16, Issue 2, 261-284

P Craig and G de Burca, EU Law (Oxford University Press, 2011)

DOI https://doi.org/10.1093/he/9780199576999.001.0001

Gregory J, 'Harmonisation or Deregulation - Implementing Equal Pay Law in the European Union and the United Kingdom' (1997) 27 Victoria U. Wellington L. Rev. 556-557

DOI https://doi.org/10.26686/vuwlr.v27i4.6099

European Trade Union Confederation (ETUC), 'New EU framework on public procurement. ETUC key points for the transposition of Directive 2014/24/EU' (2015) 9, available at: www.etuc.org/sites/default/files/publication/files/ces-

brochure transpo_edited 03.pdf

Heide I, 'Supranational Action Against Sex Discrimination: Equal Pay and Equal Treatment in the European Union' (1999) International Labour Review, 391

DOI: https://doi.org/10.1111/j.1564-913x.1999.tb00394.x 
Hreinsson P, 'General Principles' in C Baudenbacher (ed.) The Handbook of EEA Law (Springer, 2016), 350-356

DOI: https://doi.org/10.1007/978-3-319-24343-6 19

Janssens Ch, The Principle of Mutual Recognition in EU Law (Oxford University Press, 2013)

DOI: https://doi.org/10.1093/acprof:oso/9780199673032.001.0001

Norberg S, Johansson M, 'The History of the EEA agreement and the first twenty years of its existence' in C Baudenbacher (ed.) The Handbook of EEA Law (Springer, 2016)

DOI: https://doi.org/10.1007/978-3-319-24343-6 1

Semple A, 'Living Wages in Public Contracts: Impact of the RegioPost Judgment and the Proposed Revisions to the Posted Workers Directive' in A Sánchez Graells (ed.), Smart Public Procurement and Labour Standards (Place of publication: Hart Publishing, 2018)

DOI: https://doi.org/10.5040/9781509912841.ch-005

Skovgaard Ølykke G and Sánchez Graells A (eds.), Reformation or Deformation of the EU Public Procurement Rules (Edward Elgar, 2016)

DOI: https://doi.org/10.4337/9781785361814

Timmermans Ch, 'Creative Homogeneity' in Martin Johansson et al. (eds.) Festschrift Sven Norberg (Bruylant; Brussels, 2006)

Valsson O, 'EFTA Court is not bound to make use of ECJ rulings', 2017 Financial Times available at: www.ft.com/content/268fa1a2-ca2f-11e7-ab18-7a9fb7d6163e

Weatherill S, Law and Values in the European Union (Oxford University Press 2016) 